\title{
Reciprocal Capital Structure and Liquidity Policy: Implementation of Corporate Governance toward Corporate Performance
}

\author{
Sumani SUMANI ${ }^{1}$, Ahmad ROZIQ ${ }^{2}$
}

Received: June 14, 2020 Revised: June 28, 2020 Accepted: August 10, 2020

\begin{abstract}
The research objective examines the effect of corporate governance on capital structure and its effect on liquidity policy and corporate performance. It tests the effect of capital structure and liquidity policy on corporate governance. It also examines the effect of liquidity policy on capital structure and the effect of capital structure on liquidity policy. The study population is all manufacturing companies that went public on the Indonesia Stock Exchange in the period 2010-2019. The research population is 182 manufacturing companies. The Judgment Sampling was used and 109 companies meet the research criteria. The study used panel data for ten years so that the amount of data observed was 1090 observations. The analysis tool uses Warp Partial Least Square (WarpPLS). The results showed that corporate governance had a significant positive effect on capital structure, but corporate governance had a significant adverse effect on liquidity policy, and corporate governance had a significant positive effect on corporate performance. Furthermore, capital structure has a significant negative effect on corporate performance, but liquidity policy has no significant effect on corporate performance. Capital structure and liquidity policy are proven to be reciprocally significant positive correlations for manufacturing companies in Indonesia.
\end{abstract}

Keywords: Corporate Governance, Capital Structure, Liquidity Policy, Corporate Performance

JEL Classification Code: G34, D24, O16, G38, L25

\section{Introduction}

Is corporate governance still a problem in a country's business and economy? It is an interesting question in theoretical studies and among business people, especially in Indonesia. According to a study conducted by the World Bank, the weak implementation of the corporate governance system is one of the determinants of an acute crisis that occurred in Southeast Asia (World Bank, 1998, 2000, 2002). Besides, corporate governance also has a crucial role in increasing competition with global companies (Ehikioya, 2009).

${ }^{1}$ First Author and Corresponding Author. Associate Professor, Department of Management, Faculty of Economics and Business, University of Jember, Indonesia [Postal Address: Kampus Tegalboto, Jl. Kalimantan No.37, Kabupaten Jember, Jawa Timur 68121, Indonesia] Email: sumani@unej.ac.id

${ }^{2}$ Associate Professor, Department of Accounting, Faculty of Economics and Business, University of Jember, Indonesia. Email: ahmad.roziq@unej.ac.id

(c) Copyright: The Author(s)

This is an Open Access article distributed under the terms of the Creative Commons Attribution Non-Commercial License (https://creativecommons.org/licenses/by-nc/4.0/) which permits unrestricted non-commercial use, distribution, and reproduction in any medium, provided the original work is properly cited.
Different theories have explained corporate governance issues. Agency theory is put forward (Fama \& Jensen, 1983; Jensen \& Meckling, 1976), which is at the center of many explanations for the link between corporate governance and firm performance. Williamson (1979, 1981, 1984) suggested a transaction cost economics where the firm itself is a governance structure facing a set of contractual hazards. Shleifer and Vishny (2012) suggest a financial model under which the corporate governance system should ensure that substantial resources are managed efficiently and in the interest of the suppliers of capital, mitigating the expropriation of resources by managers.

Jensen and Meckling (1976) assert that agency problems arise when managing a company is separate from its owner. Corporate governance is a means to make companies better, among others, by inhibiting practices of corruption, collusion, nepotism, improving budget discipline, utilizing supervision, and encouraging efficiency in corporate management (Zarkasyi, 2008). According to the agency theory, if this monitoring function can be carried out properly, it will reduce agency problems. It is explained by Macey and O'Hara (2003) that corporate governance is needed to reduce agency problems between owners and 
managers. The larger number of audit committee members is expected to carry out more effective oversight. Increasing the number of members of the audit committee will increase confidence in supervision by the audit committee, because there are diverse experience and expertise, so it is expected to reduce agency problems in the company in the form of less optimal liquidity management (Karamanou \& Vafeas, 2005). According to Chtourou et al. (2005), with a bigger number of boards, the monitoring mechanism of company management will be better. Taken together, theoretical and empirical studies using agency theory as a theoretical framework suggest that conflicts of interest between managers and shareholders, managerial incentives, controlling shareholders' motives, and the existing corporate governance structure in the firm have a significant influence on the capital structure choices made by managers (Jensen \& Meckling, 1976; Berger et al., 1997; Faccio, Lang, \& Young, 2010; Vijayakumaran \& Vijayakumaran, 2019). Therefore, a firm's observed capital structure is the result of the combination of managers' incentive, controlling shareholders' objectives, and the robustness of the governance mechanisms in place to ensure the interest of outside shareholders or minority shareholders as well as the traditional financial determinants that have been typically used to explain capital structure choices.

The country has a growing, advanced, and robust industry. If the contribution of the manufacturing industry is at least $40 \%$ of GDP, Indonesia is still far below that limit (Hartanto, 2014). Nevertheless, the results of the Indonesian Manufacturing Purchasing Manager Index (PMI) survey published by the Nikkei and IHS Markit Bernard Aw amounted to 51.2 in December 2018, up from the previous month's achievement of 50.4. However, the global manufacturing index in December 2018 is at the lowest level since September 2016, which is 51.5, down from November 2018, which reached 52.0. This condition is caused by the continued decline in sales to foreign markets (Kontan.co.id., 2019). Based on the problems that have been raised previously, the importance of the research is in determining the Reciprocal Capital Structure and Company Liquidity Policy: Implementation of Corporate Governance on Company Performance.

\section{Literature Review}

\subsection{Corporate Governance and Capital Structure}

Studies have pointed out (Fidanoski et al., 2013; Motjaba et al., 2014; Mudalige \& Ekanayake, 2017; Orazalin et al., 2016; Fidanoski et al., 2013; Motjaba et al., 2014; Orazalin et al., 2016; Mudalige \& Ekanayake, 2017) that corporate governance proxies can be institutional ownership, managerial ownership, the board of directors, domestic ownership, ownership concentration, board independence, auditors' opinions, ultimate ownership, state ownership, the role of quality, board meetings, remuneration committee, CEO education, corporate disclosure, and number of meetings held.

Myers and Majluf (1984) and Safdar and Hasan (2009) found that corporate governance has a significant effect on capital structure. Nevertheless, Motjaba et al. (2014) found evidence that corporate governance did not affect capital structure. Furthermore, Siromi and Chandrapala (2017) explained that the composition of the board a significant positive effect and board committee have a significant adverse effect on capital structure; the board size, CEO duality, and managerial ownership have no significant effect on capital structure. According to Liao et al. (2015), corporate governance (board composition, CEO duality, ownership concentration, and profitability) has a significant negative relationship with the debt ratio; corporate governance (board size) shows a significant positive relationship with the debt ratio.

According to studies (Chen \& Hu, 2012; Fama \& Jensen, 1983; Jensen \& Meckling, 1976; Sun et al., 2016), at a low level of managerial ownership, ownership structure has a significant positive effect on capital structure, but in groups of companies with high managerial ownership levels, ownership structure has a significant adverse effect on capital structure. Furthermore, institutional ownership has a positive effect on the level of corporate leverage. Shyu (2013) shows ownership structure, proxied by insider ownership, has a significant negative effect on company performance. $\mathrm{Su}$ (2010) also explains that companies controlled by the government use less debt financing.

\section{H1. Corporate Governance influences Capital Structure}

\subsection{Corporate Governance and Liquidity Policy}

High liquidity in companies may be an indication of agency problems due to differences in interests between principals and agents (Jensen, 1986). Managers prefer the existence of substantial cash because this form of liquid assets is the easiest that can be used by managers for their welfare (Myers \& Rajan, 1998). Alternatively, in other words, agency problems are one of the essential determinants in a company's liquidity policy (Dittmar et al., 2003). Agency problems that occur in companies can be minimized by applying good corporate governance, one of which is by determining the optimal level of liquidity (Jensen \& Meckling, 1976).

Dittmar et al. (2003) found that companies with bad corporate governance, tended to have higher cash balances compared to companies with good corporate governance. Bokpin et al. (2011) and Luo and Hachiya (2005) found a positive relationship between foreign ownership and 
corporate cash holding. However, if corporate governance is proxied by managerial ownership, the results are negatively correlated with cash holding (Bokpin et al., 2011; Papaioannou et al., 1992).

The application of corporate governance with the proxy of managerial ownership will build harmony between the interests of principals and agents so that managers act according to the wishes of shareholders (Jensen \& Meckling, 1976). If managerial ownership is low, then the incentive for the manager to misuse company assets through the accumulation of cash holding will be higher, so that it can reduce the value of shareholders. Nevertheless, if managerial ownership is high, then managers will be motivated to increase the value of the company and be wiser in the use of company cash. Ozkan and Ozkan (2004) support that there is a significant positive relationship between managerial ownership and cash holding. Luo and Hachiya (2005) also find that insider ownership has a positive effect on the company's cash holding level. Christina and Ekawati (2014) and Luo and Hachiya (2005) found that institutional ownership negatively affected the company's cash holding. Corporate liquidity policy is proxied by cash holding, current ratio, liquid ratio, absolute liquid ratio, cash conversion cycle, and working capital (Bagchi \& Chakrabarti, 2014; Bokpin et al., 2011; Wasiuzzaman, 2019).

\section{H2. Corporate Governance influences Liquidity Policy}

\subsection{Corporate Governance and Corporate Performance}

Company performance is the result of activities in return on investment within a specified period. Company performance is used for evaluation and in the decisionmaking by certain parties. Performance evaluation can be divided into two categories, namely, based on financial performance and based on market information (firm value). According to Ross et al. (2010), firm value is the same as the market value of debt and equity, minus cash and cash equivalents of the company. Saidat et al. (2019) shows that corporate financial performance is proxied by return on assets (accounting-based) and Tobin's Q (market-based), and has a significant adverse effect on the performance of family firms. In non-family firms, there is no systematic relationship with corporate performance (Nguyen \& Nguyen, 2020).

Corporate governance has a significant positive effect on corporate performance (Bhatt \& Bhatt, 2014; Kasozi \& Ngwenya, 2010; Myers \& Majluf, 1984; Orazalin et al., 2016). There was a significant positive relationship between corporate governance (board composition and board size) and financial performance. Ownership structure which is proxied by insider ownership and institutional ownership has a significant positive effect on corporate performance (Lin \& Fu, 2017; Shyu, 2013). However, Alucha and Bogumil (2017) show that corporate governance proxied by the concentration of ownership by majority shareholders have a significant adverse effect on corporate performance. In contrast, Mollah et al. (2012) showed that scattered ownership could improve corporate performance and reduce agency conflict. Mardnly et al. (2018) shows that corporate governance that is proxied by board of directors, auditing, disclosure, and ownership structure, apparently, only ownership structure has a significant positive effect on corporate performance (return on assets and earnings per share). Furthermore, in the ownership structure, only foreign ownership items have a significant positive effect on corporate performance. Ofoeda (2017) also shows a positive relationship between board size, audit committee size, meetings of the audit committee, and profitability.

\section{H3. Corporate Governance influences Corporate} Performance

\subsection{Capital Structure and Corporate Performance}

Capital structure is one of the important decisions in the field of corporate finance and refer to the way that a company finances its assets by combining liabilities and equity (Gul \& Cho, 2019). Listed companies possess the basic characteristics whereby different shareholders, forming the company's ownership structure, own equity capital. Ross (1977) explains that, when a company issues new debt, it becomes a sign or signal to shareholders and investors about the company's prospects in the future. This signaling theory arises because of asymmetric information problems caused by asymmetric conditions of information existing from time to time; companies must maintain loan reserve capacity by keeping loans low. Myers and Majluf (1984) also formulated a signaling model, which was a combination of investment decisions and funding decisions.

The effect of capital structure influencing corporate performance has been proven empirically (Ikapel \& Kajirwa, 2017; Khan et al., 2013; Khanam et al., 2014; Mwangi et al., 2014; Sumani, 2015). Capital structure has a significant negative effect on financial performance. It contrasts with research (Detthamrong et al., 2017; Modigliani \& Miller, 1963) showing that capital structure has a significant positive effect on financial performance. Vithessonthi and Tongurai (2015) show that capital structure has a significant negative effect on corporate performance. However, internationally-oriented companies show that capital structure has a significant positive effect on corporate performance.

H4. Capital Structure influences Corporate Performance. 


\subsection{Liquidity Policy and Corporate Performance}

According to Brealey et al. (2007), liquidity is the ability to sell an asset to get cash in a short time, especially to settle large and unexpected bills. Companies certainly also have assets with different degrees of liquidity, so corporate liquidity policy becomes very important in each company. Takon and Ogakwu (2013) show that liquidity has a significant positive effect on return on assets. Durrah et al. (2016) also showed a significant positive effect of all liquidity ratios (current ratio, quick ratio, defensive interval ratio) on gross profit margin, operating profit margins, net profit margins, operating cash flow margins, and return on assets. Samo and Murad (2019) show liquidity (current ratio), significantly positive effect on a firm's profitability (return on assets, and return on equity). Bagchi and Chakrabarti (2014) show that liquidity management has a significant negative effect on profitability (return on investment).

\section{H5. Liquidity Policy influences Corporate Performance.}

\subsection{Capital Structure and Liquidity Policy}

Sarlija and Harc (2012) show that liquidity ratios which are proxied by current ratio, quick ratio, and cash ratio have a significant adverse effect on leverage ratios, which is proxied by debt ratio, debt to equity ratio and debt factor. However, the cash ratio does not have a significant effect of leveraging proxied by a long term debt ratio. Khanqah and Ahmadnia (2013) also explained that liquidity, which was proxied by cash flow to total assets ratio, had a significant negative effect on capital structure. However, liquidity, which was proxied by cash flow to net income ratio and cash flow to equity ratio, had a significant positive effect on capital structure. Furthermore, Takon and Ogakwu (2013) explained that liquidity is the primary financial indicator in measuring whether companies can fulfill their commitments for payment of short-term, longterm debt and, total debt ratio. Bukair (2019) shows that bank size, liquidity, and corporate age are positively correlated to the leverage ratio, supporting the trade-off theory.

Some empirical studies indicate a reciprocal relationship between capital structure and corporate liquidity policy and significant research results. Burksaitiene and Draugele (2018) show that capital structure has a significant negative effect on liquidity, meaning that a high company equity will reduce liquidity risk, conversely, high debt capital will increase liquidity risk. Dasgupta et al. (2011) state that companies with high levels of debt make cash flow negative and make cash flow more sensitive. In other words, the unfavorable capital structure can increase the level of sensitivity to cash flow. Dasgupta et al. (2011) state that there is a positive correlation between capital structure components and cash flow shock. According to Darabi et al. (2012), cash flow shock is the effect of changes in operating cash, which leads to cash holding. In contrast, research conducted by Darabi et al. (2012) shows is no correlation or effect between capital structure and cash flow sensitivity.

H6. Capital Structure affects Liquidity Policy

H7. Liquidity Policy affects the Capital Structure.

\section{Methodology}

This study aims to examine and explain the effect of exogenous variables on endogenous variables, so that the type of research used is explanatory research. Exogenous variables are corporate governance, while endogenous variables include capital structure, corporate liquidity policy, and corporate performance. The sampling method using Judgment Sampling identified as many as 109 companies, as well as research data on manufacturing companies listing on the Indonesia Stock Exchange in 2010-2019. Data analysis uses the Partial Least Square Warp (WarpPLS) to investigate the variables in the study by testing the hypothesis by performed t-test.

\section{Results and Discussion}

\subsection{Model Fit and Quality Indices Model WarpPLS}

There are ten measurements of Model Fit and Quality Indices in the WarpPLS analysis to measure the quality of structural models (Solimun et al., 2017) (see Table 1).

\subsection{Indicator Weights}

Indicator weights are used to determine the strength of the indicator as a measure of latent variables. Indicators with large weights indicate that the indicator has a strong ability to reflect latent variables. Corporate governance as an exogenous variable has three indicators, namely, independent commissioners, management ownership, and public ownership. Independent Commissioners weight 0.317, Management Ownership, has a weight of 0.255, and Public Ownership has a weight of 0.440 . All indicators of corporate governance have p-values less than 0.001 . Thus, public ownership indicators have a stronger ability to form corporate governance variables compared to the other two indicators.

The capital structure as the first mediating variable has two indicators, namely, Debt-to-Asset Ratio (DAR) and Debt-to-Equity Ratio (DER). The DAR indicator weight is 0.407 with p-value $<0.001$ and DER weights 0.613 with $\mathrm{p}$-value $<0.001$. The debt-equity ratio (DER) indicator has a stronger and more significant ability to shape the capital structure variable. Liquidity policy as the second mediating variable has three indicators, namely, cash holding, liquid 
Table 1: Model Fit and Quality Indices

\begin{tabular}{|c|c|c|c|c|}
\hline No & Model Fit and Quality Indices & Fit Criteria & Value & Result \\
\hline 1 & Average Path Coefficient (APC) & $P<0.05$ & $0.282 ; \mathrm{P}<0.001$ & Good \\
\hline 2 & Average R-Squared (ARS) & $P<0.05$ & $0.361 ; P<0.001$ & Good \\
\hline 3 & Average Adjusted R-Squared & $P<0.05$ & $0.345 ; P<0.001$ & Good \\
\hline 4 & Average Block VIF (AVIF) & Acceptable if $<5$, Ideally $<3.3$ & 2.047 & Ideal \\
\hline 5 & Average Full Collinearity VIF & Acceptable if $<5$, Ideally $<3.3$ & 2.310 & Ideal \\
\hline 6 & Tenenhaus GoF (GoF) & $\begin{array}{c}\text { Small }>0.1, \text { Medium }>0.25, \\
\text { Large }>0.36\end{array}$ & 0.527 & Large \\
\hline 7 & Symspson's Paradox Ratio (SPR) & Acceptable if $>0.7$, Ideally 1 & 0.854 & Good \\
\hline 8 & R-Squared Contribution Ratio & Acceptable if $>0.9$, Ideally 1 & 0.901 & Good \\
\hline 9 & Statistical Suppression Ratio (SSR) & Acceptable if $>0.7$ & 0.925 & Good \\
\hline 10 & $\begin{array}{l}\text { Nonlinear Bivariate Causality Direction } \\
\text { Ratio (NLBCDR) }\end{array}$ & Acceptable if $>0.7$ & 0.832 & Good \\
\hline
\end{tabular}

Table 2: Hypothesis Testing on the Direct Effect of WarpPLS Analysis

\begin{tabular}{|l|l|c|c|c|}
\hline No. & \multicolumn{1}{|c|}{ Influence Between Variables } & Coefficients & p-value & Description \\
\hline 1 & Corporate Governance $\rightarrow$ Capital Structure & 0.279 & 0.015 & Significance \\
\hline 2 & Corporate Governance $\rightarrow$ Liquidity Policy & -0.182 & 0.004 & Significance \\
\hline 3 & Corporate Governance $\rightarrow$ Corporate Performance & 0.363 & 0.001 & Significance \\
\hline 4 & Capital Structure $\rightarrow$ Corporate Performance & -0.216 & 0.012 & Significance \\
\hline 5 & Liquidity Policy $\rightarrow$ Corporate Performance & 0.081 & 0.110 & Not Significance \\
\hline 6 & Capital Structure $\rightarrow$ Liquidity Policy & 0.127 & 0.033 & Significance \\
\hline 7 & Liquidity Policy $\rightarrow$ Capital Structure & 0.377 & 0.011 & Significance \\
\hline
\end{tabular}

assets, and cash ratio. Cash holding indicators have a stronger ability to form variable liquidity policies. It is evidenced by the indicator weight of 0.509 with p-value $<0.001$. Corporate performance variables as endogenous variables have three indicators, namely, ROA, ROE and Tobin's Q. Tobin's Q indicators have a stronger ability to form corporate performance variables with an indicator weight of 0.492 and $p$-value 0.001 . The results of testing the direct effect hypothesis with WarpPLS are shown in Table 2.

Table 2 shows that all hypotheses were proven to be significant, except for the fifth hypothesis, which was not proven; that is, the corporate liquid policy had a significant effect on corporate performance.

\subsection{Discussion}

Hypothesis testing results indicate that corporate governance has a significant positive effect on capital structure. The meaning of the results of this study confirms that corporate governance can play a role in shaping the effectiveness of capital structure management by utilizing supervision, budget discipline, and encouraging efficiency in corporate management. The results of this study support the previous research (Fama \& Jensen, 1983; Jensen \& Meckling, 1976; Liao et al., 2015; Masnoon \& Rauf, 2014; Myers \& Majluf, 1984; Shyu, 2013; Siromi \& Chandrapala, 2017; Su, 2010; Sun et al., 2016), but do not support the research by Motjaba et al. (2014).

Hypothesis testing results indicate that corporate governance has a significant negative effect on corporate liquidity policy. These results prove that the ability of companies to make policies about liquidity will be determined by how well and effective the role of corporate governance is. The results of this study support the research by Papaioannou et al. (1992), but it contradicts other research (Bokpin et al., 2011; Luo \& Hachiya, 2005). 
The results of the study show that corporate governance has a significant positive effect on corporate performance. This condition confirms that if corporate governance, both in terms of composition and size as well as competencies, are arranged appropriately, corporate governance will play the major role in improving company performance. It is due to the effective functioning of the supervision, which will reduce the occurrence of agency costs and other transaction costs. The results of this study support the previous research (Bhatt \& Bhatt, 2014; Mardnly et al., 2018; Ofoeda, 2017; Orazalin et al., 2016; Saidat et al., 2019). However, Saidat et al. (2019) also found that corporate governance had no significant effect on the performance of non-family firms.

The results of testing the hypothesis show that capital structure has a significant negative effect on corporate performance. The results of this test confirm that companies that are mostly funded from debt will have an impact on decreasing corporate performance. This is due to an increase in financial risk, a decrease in shareholders' income, which lead to agency costs. The results of this study support the previous research (Ikapel \& Kajirwa, 2017; Khan et al., 2013; Khanam et al., 2014; Mwangi et al., 2014; Samo \& Murad, 2019; Vithessonthi \& Tongurai, 2015), but do not support the research results by Chang et al. (2010); Detthamrong et al. (2017); Modigliani and Miller (1963).

The results of hypothesis testing show that corporate liquidity policy has no significant effect on corporate performance. This phenomenon explains that the high corporate liquidity policy (cash holding, liquid assets, and cash ratio) does not have a direct impact on improving the company's operations. The corporate liquidity policy is not directly related to the addition of working capital or investment, but instead is focused on activities to reduce the cost of capital, especially in meeting unexpected funding needs and obligations that will soon be due. High liquidity may be an indication of agency problems due to differences in interests between principals and agents (Jensen, 1986). Managers prefer the existence of substantial cash because this form of liquid assets is the easiest to use by managers for their well-being (Myers \& Rajan, 1998). It means that the high liquidity of a company is not merely to improve corporate performance, but there is a tendency for the welfare of managers themselves. The results of this study do not support the research results (Bagchi \& Chakrabarti, 2014; Samo \& Murad, 2019; Takon \& Ogakwu, 2013).

Hypothesis testing that capital structure has a significant positive effect on corporate liquidity policy. Companies that have high levels of debt will undoubtedly have an impact on the high cost of capital, and ultimately will reduce the company's profitability. Declining profitability can result in a decrease in cash flow, so the company will use cash holding, liquid assets, and cash ratio to cover the cost of capital. Thus, the risk of bankruptcy experienced by the company will be higher, and the company must prepare substantial funds to anticipate the bankruptcy earlier. The results of this study support the study by Dasgupta et al. (2011), but it contradicts the research by Burksaitiene and Draugele (2018) and Darabi et al. (2012).

The results of the study show that corporate liquidity policy has a significant positive effect on capital structure. Manufacturing companies that have excellent corporate liquidity policy are formed by proper capital structure management and the capital structure with a proportion of debt that is balanced with its capital. Thus, if the company's debt is high, of course, liquidity policy in the form of cash holding, liquid assets, and cash ratio will also be high. It is because companies must provide sufficient cash balances to cover capital costs, anticipate financial risks, and other unexpected needs. The results of this study support the research by Bukair (2019); Khanqah and Ahmadnia (2013); Sarlija and Harc (2012). Nevertheless, it does not support research by Bagchi and Chakrabarti (2014).

\section{Conclusion}

The results of the study state that corporate governance has a significant positive effect on the capital structure, but a significant negative effect on corporate liquidity policy and a significant positive effect on corporate performance. Capital structure has a significant negative effect on corporate performance, and liquidity policy is not significantly correlated with corporate performance. Capital structure has a significant positive effect on corporate liquidity policy, and liquidity policy has a significant positive effect on capital structure. Future studies should include corporate governance indicator variables, namely, institutional ownership, the board of directors, domestic ownership, ownership concentration, auditors' opinions, ultimate ownership, state ownership, the role of quality, board meetings, remuneration committees, and several meetings held.

This research is expected to provide input for companies managing corporate governance by paying more attention to capital structure and corporate liquidity policy in optimizing corporate performance, to improve the welfare of shareholders and stakeholders. Besides, companies must also be aware that investors will conduct an assessment of the application of corporate governance in the feasibility analysis of investment decisions. Furthermore, it can enrich the conceptual discussion and consolidate the study of corporate governance, through agency theory developed by Jensen and Meckling (1976) and Fama and Jensen (1983), transaction costs introduced by Williamson (1979, 1981, 1984), as well as financial models (Shleifer \& Vishny, 2012), and signaling theory (Ross, 1977). 


\section{References}

Alucha, M., \& Bogumil, K. (2017). Ownership Structure and Company Performance: A Panel Study from Poland. Baltic Journal of Management. 12(1). https://doi.org/https://doi. org/10.1108/BJM-01-2017-0025

Bagchi, B., \& Chakrabarti, J. (2014). Modelling Liquidity Management for Indian FMCG Firms. International Journal of Commerce and Management, 24(4), 334-354. https://doi.org/ https://doi.org/10.1108/IJCoMA-10-2012-0065

Bhatt, P., \& Bhatt, R. (2014). Corporate Governance and Firm Performance in Malaysia. The International Journal of Business in Society, 17(5), 896-912. https://doi.org/. https://doi. org/10.1108/CG-03-2016-0054

Berger, P. G., Ofek, E., \& Yermack, D. L. (1997). Managerial entrenchment and capital structure decisions. Journal of Finance, 52, 1411-1438. https://doi.org/10.1111/j.1540-6261.1997. tb01115.x

Bokpin, G. A., Isshaq, Z., \& Otchere, F. A. (2011). Ownership Structure, Corporate Governance, and Corporate Liquidity Policy. Journal of Financial Economic Policy, 3(3), 262-279. https://doi.org/https://doi.org/10.1108/17576381111152236

Brealey, R. A., Myers, S. C., \& Marcus, A. J. (2007). Fundamentals of Corporate Finance. New York, NY: McGraw-Hill Companies, Inc.

Bukair, A. A. (2019). Factors Influencing Islamic Banks' Capital Structure in Developing Economies. Journal of Islamic Accounting and Business Research, 10(1), 2-20. https://doi.org/ DOI:10.1108/JIABR-02-2014-0008

Burksaitiene, D., \& Draugele, L. (2018). Capital Structure Impact on Liquidity Management. International Journal of Economics, Business, and Management Research, 2(1), 110-127.

Chang, Y., Liu, Y., \& Chien, C. (2010). Capital Structure and Firm Value in China. A Panel Threshold Regression Analysis. African Journal of Business Management, 4(4), 1-10.

Chen, P., \& Hu, H. S. (2012). Total Quality Management \& Business Excellence The mediating role of relational benefit between service quality and customer loyalty in airline industry. September, 37-41. https://doi.org/10.1080/14783363 .2012 .661130

Christina, Y., \& Ekawati, E. (2014). Excess Cash Holding and Institutional Ownership in Manufacturing Companies Listed on the IDX. Jurnal Manajemen Strategi Bisnis Dan Kewirausahaan, 8(1), 1-10. https://ojs.unud.ac.id/index.php/ jmbk/article/view/8051 [Indonesian]

Chtourou, S. M., Bedard, J., \& Courteau, L. (2005). Corporate Governance and Earnings Management. SSRN Electronic Journal, https://doi.org/10.2139/ssrn.275053

Darabi, R., Adeli, M., \& Torkamani, M. (2012). The Effect of Cash Flow Shocks on Capital and Asset Structure (Evidence from Tehran Stock Exchange). International Journal of Humanities and Social Science, 13(2), 267-275.
Dasgupta, S., Noe, T. ., \& Wang, Z. (2011). Where did are Dollar Go? The Effect of Cash Flow Shocks on Capital and Asset Structure. Journal of Financial and Quantitative Analysis, 46(5), 1259-1294.

Detthamrong, U., Chancharat, N., \& Vithessonthi, C. (2017). Corporate Governance, Capital Structure, and Firm Performance: Evidence from Thailand. Research in International Business and Finance, 42, 689-709. https://doi. org/DOI: 10.1016/j.ribaf.2017.07.011

Dittmar, A., Smith, J. ., \& Servaes, H. (2003). International Corporate Governance and Corporate Cash Holding. Journal of Financial and Quantitative Analysis, 38(1), 111-133.

Durrah, O., Rahman, A. A. A., Jamil, S. ., \& Ghafeer, N. A. (2016). Exploring the Relationship between Liquidity Ratios and Indicators of Financial Performance: An Analytical Study on Food Industrial Companies Listed in Amman Bursa. International Journal of Economics and Financial Issues, 6(2), 435-441.

Ehikioya, B. (2009). Corporate Governance Structure and Firm Performance in Developing Economies: Evidence from Nigeria. Corporate Governance: The International Journal of Business in Society, 9(3), 231-243.

Faccio, M, Lang, L. H. P., \& Young, L. (2010). Pyramiding vs leverage in corporate groups: International evidence. Journal of International Business Studies, 41(1), 88-104. https://doi. org/10.1057/jibs.2009.33

Gul, S., \& Cho, H. R. (2019). Capital structure and default risk: evidence from Korean stock Market. Journal of Asian Finance, Economics and Business, 6(2), 15-24. https://doi.org/10.13106/ jafeb.2019.vol6.no2.15.

Fama, E. F., \& Jensen, M. C. (1983). Separation of Ownership and Control Source. Separation of Ownership and Control Source, 26(2), 301-325.

Fidanoski, F., Mateska, V., \& Simeonovski, K. (2013). Corporate Governance and Bank Performance: Evidence from Macedonia. Proceedings of 16th International Students' Conference, Faculty of Economics and Administrative Sciences, Ege University, Izmir, Turkey, April 2013.

Hartanto, E. (2014). Opportunities and Challenges in the Industrial Sector Facing the National, Regional, Global Economy in the future. Retrieved December 15, 2019 from: http://rocana. kemenperin.go.id/index.php/download/category/412014?down load $=444 \% 3$ A04-p-p-p-p [Indonesian]

Ikapel, O. ., \& Kajirwa, I. (2017). Analysis of Long Term Debt and Financial Performance of State-Owned Sugar Firms in Kenya. International Journal of Commerce and Management Research, 3(2), 108-111.

Jensen, M. C. (1986). Agency Costs of Free Cash Flow, Corporate Finance and Takeovers. American Economic Review, 76(2), 323-339. https://www.jstor.org/stable/1818789?seq=1

Jensen, M. C., \& Meckling, W. H. (1976). Theory of the Firm: Managerial Behavior, Agency Costs, and Ownership Structure. 
Journal of Financial Economics, 3(4), 305-360. https://doi.org/ https://doi. org/10.1016/0304-405X(76)90026-X

Karamanou, I., \& Vafeas, N. (2005). The Association between Corporate Boards, Audit Committees, and Management Earnings Forecasts: An Empirical Analysis. Journal of Accounting Research, 43(3), 453-486.

Kasozi, J., \& Ngwenya, S. (2010). The Capital Structure Practice of Listed Firms in South Africa. Corporate Ownership \& Control, 8(1-6), 624-636. DOI:10.22495/cocv8i1c6p4

Khan, F. N., Niazi, G. S. ., \& Akram, T. (2013). Impact of Capital Structure on Firm Financial Performance: A Case of The Pakistani Engineering Firms Listed on KSE. International Journal of Information, Business, and Management, 5(2), 218-240.

Khanam, F., Nasreen, S., \& Pirzada, S. (2014). Impact of Capital Structure on Firm's Financial Performance: Evidence from the Food Sector of Pakistan. Research Journal of Finance and Accounting, 5(11), 93-104.

Khanqah, V., \& Ahmadnia, L. (2013). The Impact of Capital Structure on Liquidity and Investment Growth Opportunity in the Teheran Stock Exchange. Journal of Basic and Applied Scientific Research, 3(4), 463-470.

Kontan.co.id. (2019, January). PMI Index Reflects Increased Manufacturing Activity at the End 2018. Retrieved March 15, 2020 from: https://insight.kontan.co.id/news/indeks-pmicerminkan-peningkatan-kegiatan-manufaktur-di-akhir-2018 [Indonesian]

Liao, L. ., Mukherjee, T., \& Wang, W. (2015). Corporate Governance and Capital Structure Dynamics: An Empirical Study. The Journal of Financial Research, 38(2), 169-191. https://doi.org/ https://doi.org/10.1111/jfir.12057

Lin, Y. ., \& Fu, X. (2017). Does Institutional Ownership Influence Firm Performance? Evidence from China. International Review of Economic Finance, 49, 17-57.

Luo, Q., \& Hachiya, T. (2005). Corporate Governance, Cash Holdings, and Firm Value: Evidence from Japan. Review of Pacific Basin Financial Markets and Policies, 8(4), 613-636.

Nguyen, H. T., \& Nguyen, A. H. (2020). The Impact of Capital Structure on Firm Performance: Evidence from Vietnam. Journal of Asian Finance, Economic and Business. 7(4), 97105. https://doi.org/https;//doi.or/10.13106/jafeb.2020.vol7. no4.97

Macey, J., \& O'Hara, M. (2003). The Corporate Governance of Bank, Federal Reserve Bank of New York. Economic Policy Review, 9(1), 91-107.

Mardnly, Z., Mouselli, S., \& Abdulraouf, R. (2018). Corporate Governance and Firm Performance: an Empirical Evidence from Syria. International Journal of Islamic and Middle Eastern Finance and Management, 11(4), 591-607.

Masnoon, M., \& Rauf, M. (2014). Impact of Corporate Governance on Capital Structure - A Study o KSE Listed Firms. Global Management Journal for Academic \& Corporate Studies, 3(1), 94-110.
Modigliani, F., \& Miller, H. M. (1963). Corporate Income Taxes and the Cost of Capital: A Correction. The American Economic Review, 53(3), 433-443. http://www.jstor.org/stable/1809167

Mollah, A. S., Farooque, O. A., \& Karim, W. (2012). Ownership structure, corporate governance and firm performance: Evidence from an African emerging market. Studies in Economics and Finance, 29(4), 301-319. https://doi.org/DOI: $10.1108 / 10867371211266937$

Motjaba, N., Poor, A., \& Sadeghi, Z. (2014). The Relationship between Corporate Governance, Capital Structure, and Systematic Risk in those Firms Listed at Tehran's Stock Exchange, Iran. Research Journal of Recent Sciences, 3(12), 67-74.

Mudalige, N., \& Ekanayake, A. (2017). The Influence of Corporate Governance on Capital Structure Decisions of Listed Companies in Sri Lanka. Modern Sri Lanka Studies, 6(1), 33-45.

Mwangi, L., Makau, M., \& Kosimbei, G. (2014). Relationship between Capital Structure and Performance of Non-Financial Companies Listed in the Nairobi Securities Exchange Kenya. Global Journal of Contemporary Research in Accounting, Auditing, and Business Ethics, 1(2), 77-90.

Myers, S., \& Rajan, R. (1998). The Paradox of Liquidity. The Quarterly Journal of Economics, 113(3), 733-741.

Myers, S. C., \& Majluf, N. S. (1984). Corporate financing and investment decisions when firms have information that investors do not have. Journal of Financial Economics, 13(2), 187-221. https://doi.org/10.1016/0304-405X(84)90023-0

Ofoeda, I. (2017). Corporate Governance and Non-Bank Financial Institutions Profitability. International Journal of Law and Management, 59(6), 854-875.

Orazalin, N., Mahmood, M., \& Lee, K. (2016). Corporate governance, financial crises and bank performance: lessons from top Russian banks. Corporate Governance: The International Journal of Business in Society, 16(5), 798-814. https://doi.org/https://doi.org/10.1108/CG-10-2015-0145

Ozkan, A., \& Ozkan, N. (2004). Corporate Cash holding: an Empirical Investigation of UK Companies. Journal of Banking \& Finance, 28(9), 2103-2134. https://doi.org/https://doi. org/10.1016/j.jbankfin.2003.08.003

Papaioannou, G., Strock, E., \& Travlos, N. (1992). Ownership Structure and Corporate Liquidity Policy. Managerial and Decision Economics, 13(4), 315-322. https://www.jstor.org/ stable $/ 2487763$

Ross, S. A. (1977). The Determination of Financial Structure: The Incentive-Signalling Approach. The Bell Journal of Economics, 8(1), 23-40. https://doi.org/DOI: 10.2307/3003485

Ross, S. A., Westerfield, R. ., \& Jordan, B., D. (2010). Fundamentals of Corporate Finance $\left(9^{\text {th }}\right.$ ed.). New York, NY: The McGrawHill Companies, Inc.

Safdar, A., \& Hasan, M. (2009). Impact of Ownership Structure and Corporate Governance on Capital Structure of Pakistani Listed Companies. International Journal of Business and Management, 4(2), 50-57. https://doi.org/DOI:10.5539/ijbm.v4n2p50 
Saidat, Z., Silva, M., \& Seaman, C. (2019). The relationship between Corporate Governance and Financial Performance. Journal of Family Business Management, 9(1), 54-78. https:// doi.org/. https://doi.org/10.1108/JFBM-11-2017-0036

Samo, A., \& Murad, H. (2019). Impact of Liquidity and Financial Leverage on Firm's Profitability-an Empirical Analysis of the Textile Industry of Pakistan. Research Journal of Textile Apparel, 23(4), 291-305. https://doi.org/. https://doi. org/10.1108/RJTA-09-2018-0055

Sarlija, N., \& Harc, M. (2012). The Impact of Liquidity on the Capital Structure: A Case Study of Croatian Firms. Business Systems Research, 3(1), 30-36. https://doi.org/DOI: https://doi. org/10.2478/v10305-012-0005-1

Shleifer, A., \& Vishny, R. (2012). A Survey of Corporate Governance. The Journal of Finance, 52(2), 737-783. https:// doi.org/https://doi.org/10.1111/j.1540-6261.1997.tb04820.x

Shyu, J. (2013). Ownership Structure, Capital Structure, and Performance of Group Affiliation: Evidence from Taiwanese Group-Affiliated Firms. Managerial Finance, 39(4), 404-420. https://doi.org/DOI: 10.1108/03074351311306210

Siromi, B., \& Chandrapala, P. (2017). The Effect of Corporate Governance on Firms' Capital Structure of Listed Companies in Sri Lanka. Journal of Competitiveness, 9(2), 19-33. https:// doi.org/10.7441/joc.2017.02.02

Solimun, Fernandes, A. A. R., \& Nurjannah. (2017). Multivariate Statistics Method: Structural Equation Modeling (SEM) WarpPLS Approach. Kota Malang, Indonesia: Universitas Brawijaya Press. [Indonesian]

Su, L. D. (2010). Ownership Structure, Corporate Diversification, and Capital Structure. Management Decision, 48(2), 314-339. https://doi.org/DOI: 10.1108/00251741011022644

Sumani, S. (2015). Determinan Struktur Modal dan Nilai Perusahaan Pertammbangan Pasca UU Nomor 4 Tahun 2009. Jurnal EKUITAS, 19(1), 24-41.

Sun, J., Ding, L., Guo, M., \& Li, Y. (2016). Ownership, Capital Structure, and Financing Decision Evidence from the UK. British Accounting Review, 48(4), 448-463. https://doi.org/ https://doi.org/10.1016/j.bar.2015.04.001

Takon, S. M., \& Ogakwu, V. (2013). Impact of Liquidity on Return on Assets of Firms: Evidence from Nigeria. International
Journal of Management \& Information Technology, 6(3), 885-894. https://doi.org/DOI: https://doi.org/10.24297/ijmit. v6i3.728

Vithessonthi, C., \& Tongurai, J. (2015). The Effect of Leverage on Performance: Domestically-Oriented Versus InternationalityOriented Firm. Research in International Business and Finance, 34, 265-280. https://doi.org/DOI: 10.1016/j.ribaf.2015.02.016

Vijayakumaran, S \& Vijayakurmaran. R. (2019). Corporate Governance and Capital Structure Decisions: Evidence from China Listed Companies. Journal of Asian Finance, Economics and Business. 6(3), 67-79. https://doi.org/DOI: https://doi. org/10.13106/jafeb.2019.vol6.no3.67

Wasiuzzaman, S. (2019). Geographical Diversification and corporate Liquidity in Malaysia: A Quantile Regression Approach. Pacific Accounting Review, 32(2), 125-146. https:// doi.org/DOI: https://doi.org/101108/PAR-09-2019-0118

Williamson, O. E. (1979). Transaction-cost economics: the governance of contractual relations. Journal of Law and Economics, 22(2), 233-261. http://www.jstor.org/stable/725118

Williamson, O. E. (1981). The economics of organization: the transaction cost approach. American Journal of Sociology, 87(3), 548-577. https://www.jstor.org/stable/2778934

Williamson, O. E. (1984). Corporate governance. The Yale Law Journal, 93(7), 1197-1230. https://www.jstor.org/stable/ i2 232654

World Bank. (1998). East Asia: The Road to Recovery. Retrieved March 15, 2020 from: http://documents.worldbank.org/curated/ en/364021468770639382/East-Asia-the-road-to-recovery

World Bank. (2000). Corporate Governance: A Framework for Implementation. Retrieved March 15, 2020 from: http:// documents.worldbank.org/curated/en/810311468739547854/ Corporate-governance-a-framework-for-implementation

World Bank. (2002). The State of Corporate Governance: Experience from Country Assessments. Retrieved March 15, 2020, from: http://documents.worldbank.org/curated/ en/419361468764404142/The-state-of-corporate-governanceexperience-from-country-assessments

Zarkasyi, W. (2008). Good Corporate Governance in Manufacturing, Banking and Other Financial Services. Bandung, Indonesia: Alfabeta. [Indonesian] 